\title{
Comparing the Efficacy of Local Triamcinolone Injection in Carpal Tunnel Syndrome Using Three Different Approaches with or without Ultrasound Guidance [Letter]
}

This article was published in the following Dove Press journal:

Journal of Pain Research

Jiaming Zhou

Yuan Xue $\mathbb{D}$

Department of Orthopaedic Surgery, Tianjin Medical University General Hospital, Tianjin, People's Republic of China
Correspondence: Yuan Xue

Department of Orthopaedic Surgery,

Tianjin Medical University General

Hospital, Tianjin, People's Republic of China

Tel +86 $22608 \mid 4688$

$\mathrm{Fax}+862227219052$

Email xueyuanzyy@I63.com

\section{Dear editor}

We read the article by Rayegani et al with great interest. ${ }^{1}$ In their study, the authors compared three methods (landmark-guided, conventional ultrasound-guided midline approach and ultrasound-guided ulnar in-plane method) in the treatment of carpal tunnel syndrome (CTS) and found that all of these three methods could improve pain intensity, function and electrophysiologic and radiographic outcomes. In addition, no statistical differences were found among the three groups in any outcomes.

However, the unreasonable $P$ values in the study should be noted. In Table 2, five $P$ values were greater than $0.05 .{ }^{1}$ For example, the $P$ value in the ulnar in-plane group regarding Boston questionnaire symptom severity scale (BQ-SSS) was 0.542, meaning no significant difference was found in symptom severity before and after ultrasound-guided ulnar in-plane triamcinolone injection. But according to our clinical and statistical experience, nearly 50\% improvement showed a nonsignificant difference was inconceivable. Meanwhile, previous studies all showed statistical improvements in BQ-SSS after ultrasound-guided corticosteroid injection treatment. ${ }^{2-5}$ Considering the authors used paired $t$-test through SPSS software in the study, $P$ values in the Paired Samples Correlations and in the Paired Samples Test could be confused in the output document if not careful, so the $P$ values in the Paired Samples Correlations may be recorded as original $P$ values in the Paired Samples Test.

Hence, we advise the authors recalculate the data in this part. If all the $P$ values in Table 2 were less than 0.05 , the "Discussion" and "Conclusion" section should be corrected appropriately.

\section{Disclosure}

The authors report no conflicts of interest in this communication.

\section{References}

1. Rayegani SM, Raeissadat SA, Ahmadi-Dastgerdi M, Bavaghar N, Rahimi-Dehgolan S. Comparing the efficacy of local triamcinolone injection in carpal tunnel syndrome using three different approaches with or without ultrasound guidance. J Pain Res. 2019;12:2951-2958. doi:10.2147/JPR. S212948 
2. Babaei-Ghazani A, Nikbakht N, Forogh B, et al. Comparison between effectiveness of ultrasound-guided corticosteroid injection above versus below the median nerve in mild to moderate carpal tunnel syndrome: a randomized controlled trial. Am J Phys Med Rehabil. 2018;97(6):407-413. doi:10.1097/PHM.0000000000000877

3. Eslamian F, Eftekharsadat B, Babaei-Ghazani A, Jahanjoo F, Zeinali M. A randomized prospective comparison of ultrasound-guided and landmark-guided steroid injections for carpal tunnel syndrome. $J$ Clin Neurophysiol. 2017;34(2):107-113. doi:10.1097/WNP.0000000000000 342
4. Lee JY, Park Y, Park KD, Lee JK, Lim OK. Effectiveness of ultrasound-guided carpal tunnel injection using in-plane ulnar approach: a prospective, randomized, single-blinded study. Medicine. 2014;93(29):e350. doi:10.1097/MD.0000000000000350

5. Ustün N, Tok F, Yagz AE, et al. Ultrasound-guided vs. blind steroid injections in carpal tunnel syndrome: A single-blind randomized prospective study. Am J Phys Med Rehabil. 2013;92(11):999-1004. doi:10.1097/PHM.0b013e31829b4d72

Dove Medical Press encourages responsible, free and frank academic debate. The content of the Journal of Pain Research 'letters to the editor' section does not necessarily represent the views of Dove Medical Press, its officers, agents, employees, related entities or the Journal of Pain Research editors. While all reasonable steps have been taken to confirm the content of each letter, Dove Medical Press accepts no liability in respect of the content of any letter, nor is it responsible for the content and accuracy of any letter to the editor.

Journal of Pain Research

\section{Dovepress}

\section{Publish your work in this journal}

The Journal of Pain Research is an international, peer reviewed, open access, online journal that welcomes laboratory and clinical findings in the fields of pain research and the prevention and management of pain. Original research, reviews, symposium reports, hypothesis formation and commentaries are all considered for publication. The manuscript management system is completely online and includes a very quick and fair peer-review system, which is all easy to use. Visit http:// www.dovepress.com/testimonials.php to read real quotes from published authors. 